\title{
THE DESCRIPTION OF HISTOPATHOLOGY IN BREAST CANCER PATIENTS AT RSUP.H. ADAM MALIK MEDAN
}

\author{
Ice Ratnalela Siregar \\ Dosen Jurusan Analis Kesehatan Poltekkes Medan
}

\begin{abstract}
Breasts are an important organ for women. Breasts can experience various disorders or diseases, both serious and mild disease. Among these are breast cancer which is one of the most dreaded breast abnormalities. Breast cancer is a cancer that comes from the gland, glandular, and breast support tissue.Breast cancer has been known to attack only women. In fact, malignant tumors are also biased also against men. The histopathologic feature is a diagnostic feature of breast cancer. The purpose of this study was to determine the histopathologic description of Breast Cancer at RSUP.H.Adam Malik. The sample in this study is all breast cancer patients who have been diagnosed by doctors who visit the RSUP.H.Adam Malik (Population). The research method used is descriptive of taking secondary data in medical record at RSU.H.Adam Malik. The results of this study can be seen that of 60 breast cancer patients who do biopsy, the majority of patients have histopathology of breast cancer invasive Ductal Carcinoma as much as 31 people (51.66\%) and Invasive Breast Cancer Nos Type of 29 people (48.34\%).
\end{abstract}

Keywords : Breast Cancer, Histopatology

\section{PENDAHULUAN}

Payudara adalah organ yang penting bagi kaum wanita. Kebanyakan kaum wanita yang sudah beberapa kali melahirkan merasa risau dengan payudaranya.Padahal yang harus dirisaukan oleh kaum wanita seharusnya adalah sehatkah payudara yang dimilikinya, Payudara dapat mengalami berbagai kelainan atau gangguan penyakit, baik penyakit berat maupun ringan. Di antaranya adalah kanker payudara yang merupakan salah satu kelainan payudara yang paling ditakuti. Kanker payudara adalah kanker yang berasal dari kelenjar, saluran kelenjar, dan jaringan penunjang payudara(Bustan, 2007).

Data statistik menunjukkan bahwa wanita di seluruh dunia lebih banyak yang terserang kanker payudara dari pada tipe kanker lain. Diperkirakan 1,2 juta wanita terdiagnosis terkena kanker payudara, 500.000 di antaranya meninggal. Di Amerika Serikat, pada tahun 1940, risiko hidup wanita terkena kanker payudara adalah 1 dari 22 wanita. Pada tahun 2002 meningkat menjadi 1 dari 8 wanita. Diperkirakan bahwa 203.500 wanita telah terdiagnosis terkena kanker payudara dan 40.000 wanita meninggal karena kanker payudara. Jumlah tersebar wanita yang terkena kanker payudara, terdapat di negara-negara industry (Bustan, 2007).

Kanker payudara selama ini dikenal hanya menyerang wanita. Padahal, faktanya tumor ganas ini bias juga menyerang kaum laki-laki. Di Indonesia, perbandingan penderita kanker pria dan wanita adalah 1:1000. Peluangnya memang sangat kecil dibandingkan wanita, karena pria memproduksi lebih sedikit hormone estrogen, yaitu hormon wanita yang diketahui menjadi salah satu kontributor terjadinya kanker payudara (Bustan, 2007)

Di Negara berkembang setiap tahunnya lebih dari 580.000 kaus kanker payudara di temukan kurang lebih 372.000 pasien meninggal karena penyakit ini. Data WHO (World Health Organization) menunjukkan bahwa 78\% kanker payudara terjadi pada wanita usia 50 tahun keatas, sedangkan $6 \%$ nya pada usia 40 tahun. Tahun 2010 WHO memperkirakan angka kejadian terkena kanker payudara terdapat 11 juta dan tahun 2030 akan bertambah menjadi 27 juta kematian akibat kanker (WHO, 2010).

Tingginya kanker serviks di Indonesia membuat WHO menempatkan Indonesia sebagai Negara dengan jumlah penderita kanker serviks terbanyak. Menurut WHO jumlah penderita kanker di dunia setiap tahun bertambah sekitar 7 juta orang, dan dua pertiga diantaranya berada di negara-negara yang sedang berkembang. Jika tidak di kendalikan, diperkirakan 26 juta orang akan menderita kanker dan 17 juta meninggal karena kanker pada tahun 2030. Ironisnya kejadian ini akan terjadi lebih cepat di Negara berkembang (WHO, 2010).

Berdasarkan data dari Kemenkes saat ini penderita kanker payudara pada wanita dengan prevalensi sebesar 1,4 juta jiwa pada tahun 2008 dengan angka kematian sebesar 458.400 jiwa, Kanker payudara di Amerika merupakan kanker invasive yang paling sering terdiagnosis pada wanita. Angka kejadiaan kanker payudara di Australia pada tahun 2010 adalah sekitar 14.308 kasus baru (Kemenkes, 2008). 
Di Indonesia tiap tahun di perkirakan terdapat 100 penderita baru per 100.000 penduduk. Ini berarti dari 237 juta penduduk, ada sekitar 237.000 penderita Kanker baru setiap tahunnya. Sejalan dengan itu, data empiris juga menunjukkan bahwa kematian akibat kanker dari tahun ketahun semakin meningkat. Berdasarkan hasil Rikesda tahun 2007, sekitar 5,7\% kematian semua umur di sebabkan kanker ganas. Berdasarkan hasi penelitian Tjandra Yoga, di Indonesia prevalensi kanker adalah 4,3 per 1000 penduduk (Zumaroh, 2011)

Insiden kanker payudara di Jawa Barat khususnya di RS Hasan Sadikin Bandung pada tahun 2009 adalah 275 kasus, dengan prevalensi kelompok umur tertinggi 40-49 tahun, pada pria terdapat 0,36 \% kasus dan pada wanita 99,64\%, jenis histopatologi yang paling banyak adalan invasive ductul carcinoma yaitu sebesar 60,3\%(Zumaroh, 2011).

Di Yogyakarta, tingkat prevalensi kanker mencapai 9,6 per 1000 orang, Angka tersebut lebih tinggi dari nilai rata-rata prevalensi nasional yaitu sebesar 4,3 per 1000 orang. Di Kabupaten Bantul terdapat 114 penderita kanker payudara yang meninggal 1 orang, Data dari rekam medis RSUD Yogyakarta, terdapat 60 kasus pada tahun 2012. Terdapat 16 penderita pada stadium II A, dan penanganannya di lakukan dengan operasi(Agustini,2013)

Rumah Sakit Haji Adam Malik merupakan rumah sakit pemerintah yang di kelola pemerintah pusat. Rumah Sakit Haji Adam Malik mulai berfungsi sejak tanggal 17 Juni 1991 dengan pelayanan rawat jalan, sedangkan pelayanan rawat inap dimulai tanggal 2 Mei 1992. Rumah Sakit Haji Adam Malik merupakan rumah sakit Tipe A sesuai dengan SK Menkes No. 335/Menkes/SK/VII/1990. Berdasarkan data rekam medis tahun 2016 terdapat 187 kasus kanker payudara, sedangkan 2017 terdapat 150 kasus, walaupun terjadi penurunan kasus dari tahun sebelumnya tetapi berdasarkan data penderita kanker payudara di Indonesia, terjadi peningkatan yang sangat signifikan (Profil RSUP.H.Adam Malik, 2017).

\section{METODE}

Metode Pemeriksaan yang digunakan adalah dengan cara langsung yaitu membuat jaringan biopsy dari penderita kanker payudara yang telah di dagnosa oleh dokter.

\section{Alat-alat, Bahan dan Reagensia Alat-alat Histopatologi}

Alas dari bahan kayu/plastic, cassette ukuran $3 \times 4 \times 1 \mathrm{~cm}$ untuk menaruh jaringan setelah di potong kecil-kecil, mesin otomatis Histoprosesing untuk proses dehidrasi, clearing dan impragnasi, microtom untuk memotong cassette jaringan setebal 2 mikron, Waterbath untuk mengembangkan hasil potongan jaringan yang ditaruh di atas objeck gelas, Mesin embedding untuk mencairkan, membloking dan mendinginkan blok paraffin, Scalpel/pisau aesculape untuk memotong jaringan, pinset, pinsil, pulpen, dan spidol permanen, mikroskop.

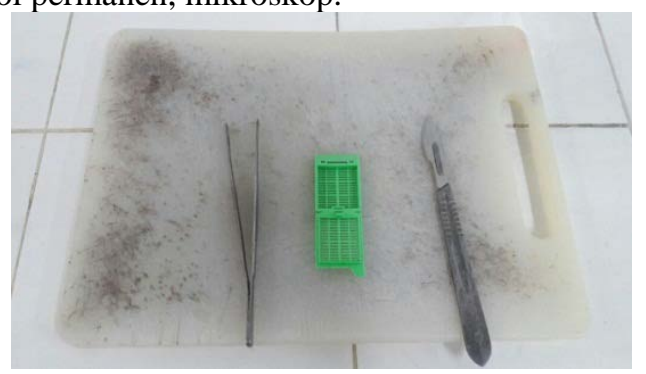

Gambar 3.1. : Alas Plastik Untuk Pemotongan Jaringan, Scapel dan Pinset

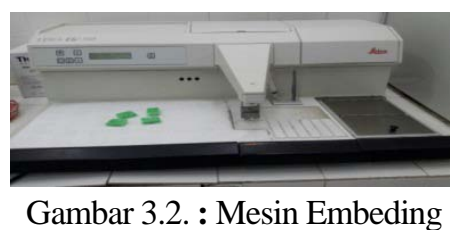

\section{Bahan}

Bahan yang digunakan Biopsy jaringan dari penderita kanker payudara yang telah diagnosa oleh dokter.

Cara Kerja Pengambilan Bahan :

1. Pengecekan kesesuaian identitas jaringan dan formulir pasien

2. Proses pemotongan Makroskopik

- Melakukan pemeriksaan specimen dan dilakukan pengukuran, pencatatan kelainan makroskopik, sesuai dengan standart pemotongan makroskopik berdasarkan organ

- Spesimen dimasukkan ke dalam kaset yang telah diberi identitas penomoran

Dilakukan perendaman di dalam formalin buffer $10 \%$ sebelum proses lanjutan

3. Pemprosesan specimen dengan mesin otomatis yang mencakup fiksasi, dehidrasi dengan alcohol bertingkat, clearing dengan xylol, dan infiltrasi dengan paraffin cair.

4. Proses penanaman specimen untuk meletakkan dan memposisikan specimen untuk meletakkan dan memposisikan specimen sedemikian rupa dalam paraffin.

5. Proses pemotongan dengan microtom

- Pemotongan kasar (Trimming) untuk menghilangkan kelebihan paraffin di atas specimen

- Pemotongan halus (Sectioning) setebal 2 mikron

6. Proses pengembangan pita paraffin specimen dengan menggunakan waterbath berisi air hangat dengan suhu 40C, dan di tempelkan pada slaid. Slaid yang sudah ditempel pita paraffin ditiriskan dengan posisi miring untuk mencegah gelembung udara.

7. Proses pemanasan dengan menggunakan Hotplate dengan suhu sesuai titik leleh paraffin yaitu 60C (Luwia Melisa, 2005) 
Reagensia

Buffer formalin 10\% Parafin, Alkohol 70\%, Alkohol 96\% dan Alkohol Absolut, Xylol, Bluing, Hematoksilin, Eosin dan Mounting.

Cara Kerja Pewarnaan :

1. Letakkan xylol, I,II,III selama 3 menit

2. Setelah itu dengan alcohol $96 \%, 80 \%$, dan $70 \%$

3. Cuci dengan air mengalir selama 1 menit

4. Setelah itu dengan lart. Hematoksilin selama 5 menit

5. Bluing selama 1 menit

6. Cuci dengan air mengalir selama 1 menit

7. Alkohol 96\% selama 1 menit

8. Kemudian berikan larutan Eosin selama 1 menit

9. Kemudian alcohol bertahap $70 \%, 80 \%$ dan $90 \%$

10. Proses penutupan slaid menggunakan kaca penutup bersih, rata, dan tipis dengan perekat (Ez mount)

11.Slaid siap di baca di mikroskop (Luwia Melisa, 2005)

\section{Hasil}

Dari data rekam medik berupa hasil pemeriksaan histopatologi di RSUP H. Adam Malik Medan periode Januari - Maret 2018, tercatat sebanyak 60 buah rekam medis kanker payudara.

Tabel 4.1

Gambaran histopatologi penderita kanker payudara berdasarkan jenis histopatologinya

\begin{tabular}{llcc}
\hline No & $\begin{array}{l}\text { Gambaran histopatologi } \\
\text { kanker payudara }\end{array}$ & F & \% \\
\hline $\mathbf{1}$ & Invasive Breast Cancer Nos & 29 & $48,34 \%$ \\
$\mathbf{2}$ & Type & 31 & $51,66 \%$ \\
& Invasive Ductal Carcinoma & & \\
\hline & Total & 60 & $100 \%$ \\
\hline
\end{tabular}

Berdasarkan tabel diatas dapat diketahui bahwa dari 60 penderita kanker payudara yang melakukan biopsi, mayoritas pasien mempunyai gambaran histopatologi kanker payudara berupa Invasive Ductal Carcinoma yaitu sebanyak 31 orang (51,66\%).

Karakteristik gambaran histopatologi penderita kanker payudara berdasarkan grade histopatologinya di RSUP H. Adam Malik dapat dijelaskan pada tabel berikut ini :

Tabel 4.2

Gambaran histopatologi penderita kanker payudara berdasarkan grade histopatologinya

\begin{tabular}{llll}
\hline No & Grade & F & \% \\
\hline $\mathbf{1}$ & Grade I & 7 & $22,59 \%$ \\
$\mathbf{2}$ & Grade II & 15 & $48,38 \%$ \\
$\mathbf{3}$ & Grade III & 9 & $29,03 \%$ \\
\hline & Total & 31 & $100 \%$ \\
\hline
\end{tabular}

Dari tabel diatas dapat disimpulkan bahwa dari 60 hasil biopsi terdapat grade pasien yang paling terbanyak dari jenis kanker Invasive Ductal Carcinoma yaitu grade II sebanyak 15 orang (48,38\%) sedangkan yang paling sedikit yaitu grade I sebanyak 7 orang (22,59\%).
Karakteristik usia penderita kanker payudara berdasarkan gambaran histopatologinya di RSUP $\mathrm{H}$. Adam Malik dapat dijelaskan pada tabel berikut ini :

Tabel 4.3

Karakteristik usia penderita kanker payudara berdasarkan gambaran histopatologi

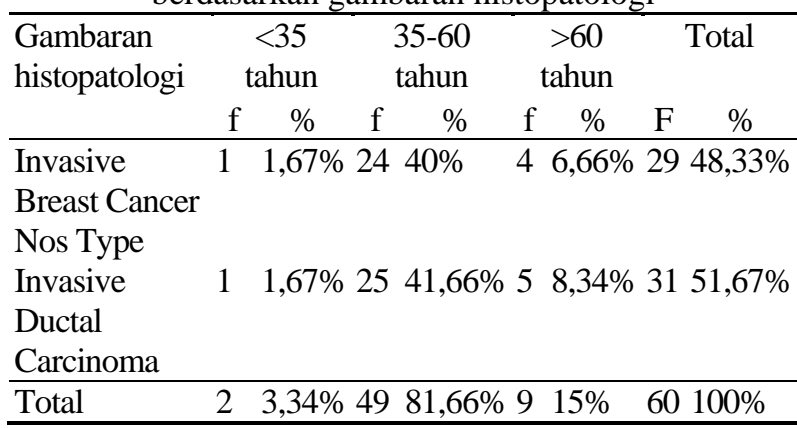

Berdasarkan data pada tabel diatas, dapat diketahui bahwa dari 60 orang penderita kanker payudara, kanker payudara paling banyak terjadi pada saat usia antara 35-60 tahun yaitu sekitar 49 orang (81,66\%), sedangkan angka kejadian yang paling sedikit adalah pasien dengan usia $<35$ tahun dengan jumlah 2 orang (3,34\%).

Karakteristik jenis kelamin penderita kanker payudara berdasarkan gambaran histopatologinya di RSUP H. Adam Malik dapat dijelaskan pada tabel berikut ini :

Tabel 4.4

Karakteristik jenis kelamin penderita kanker payudara berdasarkan gambaran histopatologinya

\begin{tabular}{lcccccc} 
Gambaran & \multicolumn{2}{c}{ Pria } & \multicolumn{2}{c}{ Wanita } & \multicolumn{2}{c}{ Total } \\
Histopatologi & F & $\%$ & f & $\%$ & F & $\%$ \\
\hline $\begin{array}{l}\text { Invasive Breast } \\
\text { Cancer Nos }\end{array}$ & 0 & 0 & 29 & $48,33 \%$ & 29 & $48,33 \%$ \\
$\begin{array}{l}\text { Type } \\
\begin{array}{l}\text { Invasive Ductal } \\
\text { Carcinoma }\end{array}\end{array}$ & 0 & 0 & 31 & $51,67 \%$ & 31 & $51,67 \%$ \\
\hline Total & 0 & 0 & 60 & $100 \%$ & 60 & $100 \%$ \\
\hline
\end{tabular}

Berdasarkan tabel 4.5 diatas, jenis kelamin penderita kanker payudara terbanyak dimiliki oleh wanita yaitu 60 orang (100\%). Pada wanita jenis tersering yaitu tipe Invasive Ductal Carcinoma yaitu 31 orang ( 51,67\%) sedangkan tidak terdapat kanker payudara pada pria.

Pembahasan

Berdasarkan tabel 4.1 dapat diketahui bahwa dari 60 penderita kanker payudara yang melakukan biopsi, mayoritas pasien mempunyai gambaran histopatologi kanker payudara berupa Invasive Ductal Carcinomayaitu sebanyak 31 orang (51,66\%). Penelitian ini sesuai dengan penelitian yang dilakukan oleh Indri Widarti di RS H. Abdul Moeloek Bandar Lampung pada tahun 2014, bahwa gambaran histopatologi jenis Invasive Ductal Carcinoma adalah paling banyak yaitu sekitar 93,5\% (Indri, 2014).

Berdasarkan hasil sampel penelitian menurut tabel 4.2 dapat disimpulkan bahwa dari 31 hasil biopsi, grade pasien kanker yang paling terbanyak dari jenis kanker Invasive Ductal Carcinoma yaitu grade II sebanyak 15 orang (48,38\%). Seorang ahli patologi akan melihat selsel kanker dibawah mikroskop dan menentukan seberapa 
jauh sel-sel tersebut masih terlihat seperti sel normal. Hal ini dinamakan grade tumor. Sel-sel kanker yang terlihat mirip sekali dengan jaringan payudara normal, memeiliki nagka grade yang rendah dan cenderung tumbuh serta menyebar lebih lambat. Secara umum, grade yang rendah mengindikasikan kemungkinan kecil untuk menyebar. Grade inni ditentukan berdasarkan susunan sel dan hubungan sel tersebut dengan yang lainnya, seberapa jauh sel tersebut mirip dengan sel payudara normal dan berapa banyak sel-sel kanker itu berada dalam proses membelah (Robbins\&Cotran, 2014).

Berdasarkan tabel 4.3 dapat diketahui bahwa kanker payudara tipe ductal Sering terjadi pada saat usia antara 35-60 tahun. Kanker payudara tipe ductal terjadi sekitar dua pertiga dari seluruh kanker payudara yang berusia $\geq 55$ tahun. Hal tersebut dikarenakan masih banyak faktor resiko lain yang mempengaruhi akan terjadinya kanker payudara.

Berdasarkan tabel 4.4 menjelaskan bahwa jenis kelamin penderita kanker payudara terbanyvak dimiliki oleh wanita yaitu 60 orang (100\%). Pada wanita jenis tersering yaitu tipe Invasive Ductal Carcinoma yaitu 31 orang ( 51,67\%). Hal ini dikarenakan wanita mengalami pajanan dari hormon estrogen lebih banyak seperti menstruasi, hamil, menyusui dan juga merupakan hormon penting wanita sedangkan pada pria hormon estrogen tidak terlalu banyak seperti pada wanita bahkan relaif sedikit. Hal tersebut menyebabkan pria jarang sekali mengalami kanker payudara (Robbins \& Cotran, 2014).

\section{Simpulan}

Berdasarkan darihasil penelitian yang telah dilakukan, data rekam medik pasien kanker payudara di RSUP H. Adam Malik Medan periode Januari - Maret 2018 ada 60 pasien kanker payudara sebagian besar memiliki karakteristik usia antara 35-60 tahun, jenis kelamin wanita, jenis histopatologi berupa Invasive Ductal Carcinoma dan grade terbanyak yaitu grade II.

Saran

1. Bagi penderita kanker payudara sebaiknya diberi asupan gizi yang cukup serta menjaga kesehatan dan kebersihan lingkungan

2. Perlunya upaya pencegahan pada wanita dengan melakukan pemeriksaan payudara sendiri (SADARI) sehingga jika ditemukan benjolan pada payudara dapat dideteksi sedini mungkin

\section{DAFTAR PUSTAKA}

Akbar Nurul, dkk, 2004, Gastroenterologi Hepatologi, Penerbit CV. Seagung Seto, Jakarta.

AlwiIdrus, dkk, 2007, Buku Ajar Ilmu Penyakit Dalam, Edisi 4 Jilid 1, Penerbit Ilmu Penyakit Dalam Fakultas Kedokteran Universitas Indonesia, Jakarta.
Aziz M. Farid, dkk, 2006, Onkologi Ginekologi, Edisi 1 Cetakan 1, Penerbit Yayasan Bina Pustaka Sarwono Prawirohardjo, Jakarta.

Bustan M. N, 2007, Epidemiologi Penyakit Tidak Menular, Penerbit Rineka Cipta, Jakarta.

Charette Jane dan Gale Danielle, 2000, Rencana Asuhan Keperawatan Onkologi, Cetakan 1, Penerbit Buku Kedokteran EGC, Jakarta.

Hacker Neville dan Moore George, 2001, Esensial Obstetri dan Ginekologi, Cetakan 1, Edisi 2, Penerbit Hipokrates, Jakarta.

HimawanSutisna, 2000, Patologi, Cetakan 11, Penerbit Bagian Patologi Anatomi Fakultas Kedokteran Universitas Indonesia, Jakarta.

Indri Widarti, 2014, Characteristic of breast cancer in young women in $H$. Abdul Moeloek Hospital Bandar Lampung, JuKeUnila

Kosasih E. N, 1992, Pemeriksaan Laboratorium Klinik, Penerbit Alumni, Bandung,

Luwia Melissa, 2005, Problematik \& Perawatan Payudara, Cetakan 3, Penerbit Kawan Pustaka, Jakarta.

MansjoerArif, dkk, 2000, Kapita Selekta Kedokteran, Edisi 3 Jilid 2, Penerbit Media Aesculapius Fakultas Kedokteran Universitas Indonesia, Jakarta.

Noer Sjaifoellah, 2010, Buku Ajar Ilmu Penyakit Dalam, Jilid 1 Edisi 3, Penerbit Fakultas Kedokteran Universitas Indonesia, Jakarta.

RamliMuchlis, dkk, 2004, Deteksi Dini Kanker, Penerbit Fakultas Kedokteran Universitas Indonesia, Jakarta.

Robbins \& Cotran. 2014. Bab 3 Payudara. Penerbit Buku kedokteran EGC. Edisi ke-6. Hlm 1141-74

Sjamsuhidajatdan Jong Wim De, 2006, Buku Ajar Ilmu Bedah, Cetakan 1, Penerbit Buku Kedokteran EGC, Jakarta. 